\section{Use of Morphometric Variables for Differentiating Breed Variations in Turkish Tazi (Sighthound) Population}

\author{
Urosevic Milivoje ${ }^{1}$, Matejevic Milosava ${ }^{2 *}$, Drobnjak Darko ${ }^{1}$ and Ozkanal Umit ${ }^{3}$ \\ ${ }^{1}$ Center for Preservation of Indigenous Breeds, Belgrade, Serbia \\ ${ }^{2}$ Faculty of Science, Trg Dositeja Obradovica 3, 21000 Novi Sad, University of Novi \\ Sad, Serbia \\ ${ }^{3}$ Faculty of Education, Eskisehir Osmangazi University, Turkey
}
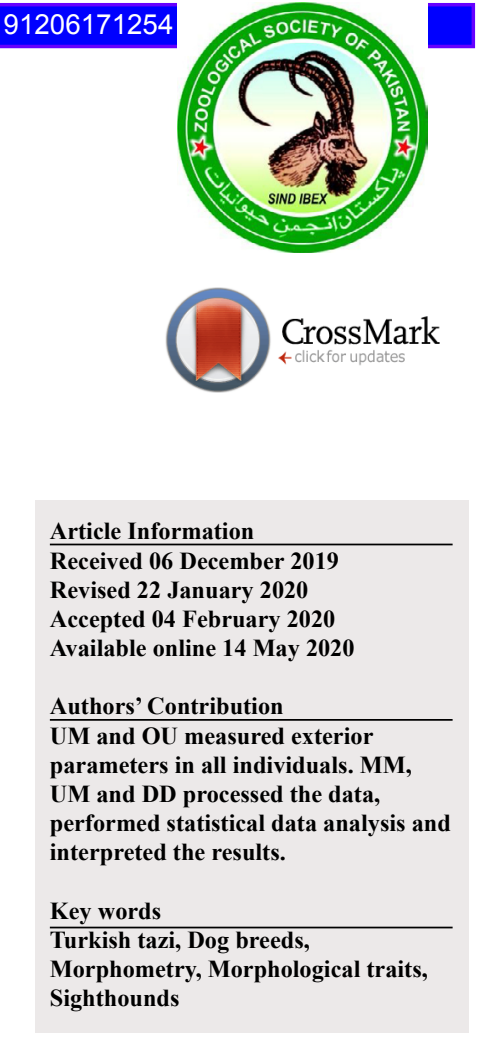

\begin{tabular}{l} 
Article Information \\
Received 06 December 2019 \\
Revised 22 January 2020 \\
Accepted 04 February 2020 \\
Available online 14 May 2020 \\
Authors' Contribution \\
\hline UM and OU measured exterior \\
parameters in all individuals. MM, \\
UM and DD processed the data, \\
performed statistical data analysis and \\
interpreted the results. \\
Key words \\
Turkish tazi, Dog breeds, \\
Morphometry, Morphological traits, \\
Sighthounds
\end{tabular}

\begin{abstract}
A B S T R A C T
Tazi is a Turkish sighthound breed that has not yet been officially recognized by the world canine organization - Fédération Cynologique Internationale (FCI). Research and analysis of morphometric parameters are required in order to write an official breed standard and recognize this breed. Previous research on this sighthound breed has shown only average values of individual morphological parameters and differences in them depending on gender, age or place of origin. However, the premise of this research is that there are several different varieties of Tazi, depending on the proportions of the body. Measurement results of 19 morphometric parameters showed that there are statistically significant differences between three sub-populations of Tazi, one with a format index greater than 100, the other with a format index less than 100 and third with a format index equal to 100. Such results are significant for setting the official breed standard in which the proportions of the body characteristic of this breed should be emphasized.
\end{abstract}

\section{INTRODUCTION}

$\mathrm{T}$ oday, there are several groups of hunting dog breeds. Hunters could hunt with hounds, pointers, retrievers, flushing dogs, leash (scent) hounds, dachshunds and each of these group has its own hunting characteristics (Matejević, 2017). Hunting dog should help the hunter in various ways by showing, raising, chasing, bringing or finding wounded game. Sighthounds are also classified as hunting breeds of dogs, one of the oldest, but they are rarely used today for hunting purposes (Taubert et al., 2007; Matejević, 2017). Sighthounds were the main hunting assistants or more precisely, the main actors of the hunt. Namely, they were chasing game, as well as the hounds. However, their goal was not to help the hunter to find the game more easily to shoot it himself, but to catch the game themselves. Sighthounds would raise their game and then use their speed to get and catch the game. The basic difference between hounds and sighthounds is that sighthounds chase game when see it, as opposed to hounds who are required to use their nose to chase game (Urosević, 2006, Taubert et al., 2007). According to the world canine organization - Fédération Cynologique Internationale (FCI),

\footnotetext{
Corresponding author: milosava@dgt.uns.ac.rs 0030-9923/2020/0005-1765 \$ 9.00/0 Copyright 2020 Zoological Society of Pakistan
}

sighthounds belong to group 10. All sighthounds are divided into three sections - (1) long-haired or fringed sighthounds, (2) rough-haired sighthounds and (3) short-haired sighthounds (http://www.fci.be /en/ nomenclature/10-Sighthounds.html). Tazi, the subject of this research, is a Turkish sighthounds breed that has not yet been officially recognized by the Fédération Cynologique Internationale.

The Tazi is a Turkish sighthound breed that has been historically bred for hunting (Y1lmaz and Ertuğrul, 2011; Yilmaz et al., 2012). Tazi is a dog breed with long and slender skull, long neck, slim body, deep chest, curved spine, long forequarters and hindquarters and a thin tail (Yilmaz, 2008). Some authors indicate that Tazi resembles, but is larger than the Saluki (Yilmaz and Ertugrul, 2012; Yilmaz, 2018). In their research, Yılmaz and Ertuğrul (2011) indicate that Turkish Tazi are moderate in size and weight. Average withers height established in their study was $62 \mathrm{~cm}$. However, earlier Tepeli (2003) states that Tazi is $68 \mathrm{~cm}$ high at rump and $49.9 \mathrm{~cm}$ long in the body (body length). Yılmaz and Ertuğrul (2011) calculated longer mean body length $(60.3 \mathrm{~cm})$ indicating that it is a midsize sighthound dog. They also found out that Turkish Tazi reached the mature body weight and size around 2 years of age, but in their next study they indicate that Tazis reach the mature body weight and size around 1 years of age (Yilmaz and Ertugrul, 2012). Celik and Yilmaz (2018) 
later, analyzed body weight of Turkish Tazi dogs and most important body measurements that can predict the body weight of Turkish Tazi. Tazi represents sighthound with short coat, and mostly black and dun. Yilmaz et al. (2012) have been analyzed body measurements of the Tazi raised in Turkish province of Konya. They found out that mean withers height is $62.0 \pm 0.44$, height at rump $2.1 \pm 0.50$, body length $60.7 \pm 0.55$, heart girth circumference $63.9 \pm 0.64$, chest depth $23.1 \pm 0.21$, abdomen depth $13.9 \pm 0.21$, chest width $17.4 \pm 0.25$, haunch width $16.4 \pm 0.18$, thigh width $2.3 \pm 0.26$, tail length $45.7 \pm 0.37$, limb length $38.9 \pm 0.31$, cannon circumference $10.2 \pm 0.11$, head length $24.0 \pm 0.36$ and ear length $12.8 \pm 0.19 \mathrm{~cm}$. Yilmaz and Ertugrul (2012) have been analyzed some morphological characteristics of Tazi raised in Turkish province of Sanliurfa. Their results were similar to previous - withers height $62.5 \pm 0.49$, height at rump $62.8 \pm 0.48$, body length $60.9 \pm 0.54$, heart girth circumference $63.5 \pm 0.57$, chest depth $22.8 \pm 0.36$, abdomen depth $14.4 \pm 0.21$, chest width $17.3 \pm 0.20$, haunch width $16.1 \pm 0.16$, thigh width $21.7 \pm 0.23$, tail length $44.6 \pm 0.41$, limb length $39.7 \pm 0.25$, cannon circumference $10.3 \pm 0.09$, head length $23.8 \pm 0.30$ and ear length $12.2 \pm 0.17 \mathrm{~cm}$. Previous research on this sighthound breed has shown only average values of individual morphological characteristics and the observed differences within trait were depending on gender, age or place of origin.

The aim of this paper is to determine if there are different groups of individuals in the population of Tazi, from the aspect of body proportions. Previous research on this sighthound breed has shown only average values of individual morphological characteristics and differences in them depending on gender, age or place of origin. However, the premise of this research is that there are three different varieties of Tazi, depending on the proportions of the body. The results of this research should determine whether there is a subpopulation of different body proportions within the population of Tazi in Turkey. Determining the existence of such varieties within a breed is of great importance for the constitution of an official breed standard in order to recognize the breed as purebred.

\section{MATERIALS AND METHODS}

Morphological parameters were measured on a total 155 individuals representing population sample of Tazi breed. Among them were 56.8\% males (88 males) and $43.2 \%$ females (67 females). These measurements were carried out during 2015 and 2016 in Turkey (region of Anatolia). The following exterior parameters i.e. the withers height (WH), height of the back (HB), height at rump (HR), height of the tail root (HTR), height of the hock $(\mathrm{HH})$, elbow height $(\mathrm{EH})$, body length $(\mathrm{BL})$, chest depth (CD), chest width (CW), chest circumference (CC), pastern circumference (PC), pelvis length (PL), rump width (RW), head length (HL), head width (HW), muzzle width (MW), muzzle lenght (ML), ear lenght (EL), hair lenght (HL) were measured in all individual dogs included in research (Figs. 1 and 2). These measurements do not have an invasive character and in no way endanger animal health. All Tazi dogs were aged between 12 months and 6 years.

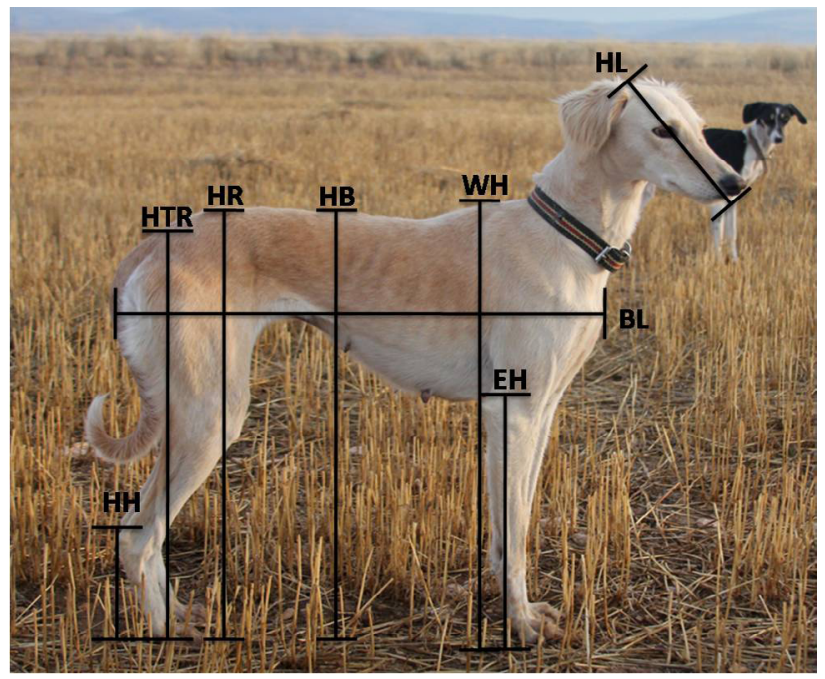

Fig. 1. Part of exterior parameters that were measured.

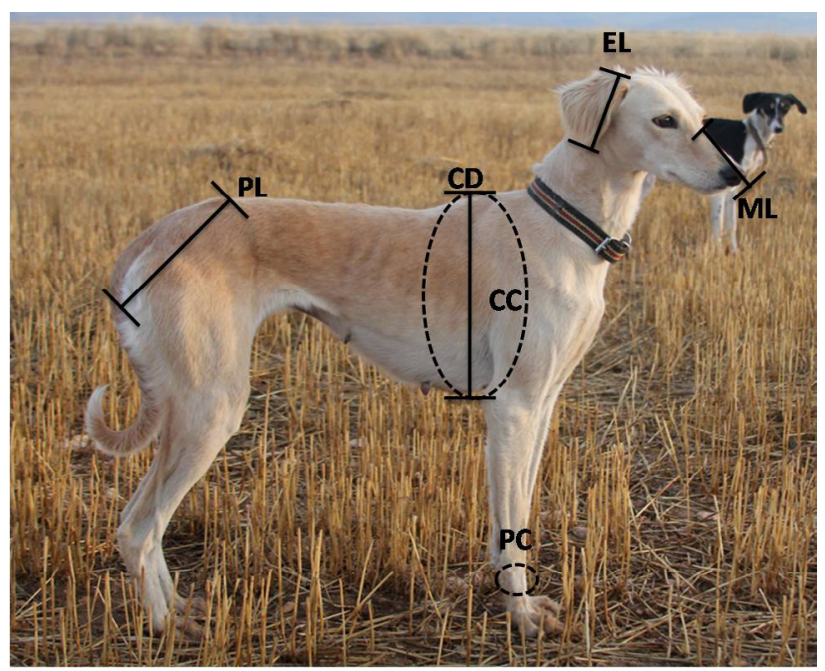

Fig. 2. Part of measured exterior parameters.

A Lydthin's measurement stick was used to measure the height at the withers (Urosević and Drobnjak, 2019). For the other parameters, a tape measure was used and all measurements were in centimeters. Conformation 
characterization was based on the mean value $(\mathrm{M})$ and standard deviation (SD) of the variables. Then, the T-test was applied in order to determine whether there is statistically significant difference among the individual characteristics and the sexes within the breed, and results are presented with $\mathrm{t}$-value $(\mathrm{t})$, degrees of freedom value (df) and significance value (sig).

For the further analysis, the frame index in this population was analyzed. The frame index in $\operatorname{dogs}$ is the ratio of body length to height at the withers (Urosević and Drobnjak, 2019). The frame index is calculated by formula: (body length / height of the withers) x 100. For breeds of square body, the index is 100 , which means that the length of the body is equal to the height of the withers. If the frame index is greater than 100 , then it is a more or less elongated body, that is, a rectangular format. As Urosević and Drobnjak (2019) state, if the frame index is greater than 100, then it is a more or less elongated body, meaning a rectangular body frame.

An analysis of variance (ANOVA) was conducted to determine differences in values of measured parameters, at the $P$ level is less than 0.05 , between the three groups formed within the observed population. Results of ANOVA are presented with F-statistic value (F), degrees of freedom value (df) and significance value ( $\mathrm{sig}$ ).

Collected data were processed using the Statistical Package for Social Sciences (SPSS) for Windows Release 23.0.0 software.

\section{Ethical approval}

No ethical approval was obtained because this study did not involve laboratory animals and only involved noninvasive procedures.

\section{RESULTS}

Official standards of every recognized breed include great number of morphometric traits, and among them the most important are WH, BL and CC. This study included larger number of morphometric characteristic. Descriptive statistics for the 19 variables used here are shown in Tables I and II.

The results show that the mean $\mathrm{WH}$ is $60.45 \mathrm{~cm}$, and the mean value of BL was $60.40 \mathrm{~cm}$. The characteristics with the lowest coefficients of variation were: PC, ML, EL, HW and HL. The greatest variability was found for $\mathrm{CC}$, and significant variability was also shown in BL and HB.

Table II shows the differences in the average values of the basic morphometric parameters between males and females. The results showed that there were no significant statistical differences between males and females between mean chest depth, rump width, muzzle width, muzzle length and hair length. T-test showed statistically significant difference between males and females for morphometric variables: $\mathrm{HL}(\mathrm{t}=5.546, \mathrm{df}=149, \mathrm{sig}=0.000), \mathrm{HW}(\mathrm{t}=$ $4.126, \mathrm{df}=153, \mathrm{sig}=0.000), \mathrm{CC}(\mathrm{t}=4.888, \mathrm{df}=153, \mathrm{sig}$ $=0.000), \mathrm{BL}(\mathrm{t}=5.804, \mathrm{df}=153, \mathrm{sig}=0.000), \mathrm{EH}(\mathrm{t}=$ 2.209, $\mathrm{df}=153, \mathrm{sig}=0.029), \mathrm{HR}(\mathrm{t}=6.114, \mathrm{df}=151, \mathrm{sig}$ $=0.000), \mathrm{HB}(\mathrm{t}=5.840, \mathrm{df}=151, \mathrm{sig}=0.000), \mathrm{WH}(\mathrm{t}=$ $7.873, \mathrm{df}=153, \mathrm{sig}=0.000), \mathrm{CW}(\mathrm{t}=2.102, \mathrm{df}=153, \mathrm{sig}$ $=0.037), \operatorname{HTR}(\mathrm{t}=4.775, \mathrm{df}=150, \operatorname{sig}=0.000), \mathrm{HH}(\mathrm{t}=$ $2.858), \mathrm{df}=153, \mathrm{sig}=0.005), \mathrm{PC}(\mathrm{t}=3.640, \mathrm{df}=153, \mathrm{sig}$ $=0.000), \operatorname{PL}(\mathrm{t}=4.074, \mathrm{df}=153$, sig $=0.000)$ and $\mathrm{EL}(\mathrm{t}=$ $4.763, \mathrm{df}=134$, sig $=0.000)$. The values of the height of the withers, the height of the back, the height at the rump, the height of the tail root in males were higher compared to the same parameters in females.

Table I. Descriptive statistic for morphometric parameters in Tazi.

\begin{tabular}{|c|c|c|c|c|}
\hline & $\mathbf{N}$ & Min-Max & $\begin{array}{l}\text { Mean } \pm \text { Stand- } \\
\text { ard deviation }\end{array}$ & $\begin{array}{l}\text { Vari- } \\
\text { ance }\end{array}$ \\
\hline Withers height $(\mathrm{cm})$ & 155 & $49.00-68.50$ & $60.44 \pm 3.37$ & 11.364 \\
\hline Height of the back $(\mathrm{cm})$ & 153 & $46.00-68.50$ & $58.39 \pm 3.57$ & 12.755 \\
\hline Height at rump $(\mathrm{cm})$ & 153 & $51.00-68.50$ & $60.41 \pm 3.39$ & 11.548 \\
\hline $\begin{array}{l}\text { Height of the tail root } \\
(\mathrm{cm})\end{array}$ & 152 & $48.00-67.50$ & $55.83 \pm 3.33$ & 11.100 \\
\hline Height of the hock $(\mathrm{cm})$ & 155 & $13.00-19.00$ & $15.92 \pm 1.34$ & 1.820 \\
\hline Elbow height $(\mathrm{cm})$ & 155 & $23.50-38.00$ & $32.70 \pm 2.02$ & 4.084 \\
\hline Body length $(\mathrm{cm})$ & 155 & $51.00-68.00$ & $60.40 \pm 3.62$ & 13.128 \\
\hline Chest depth $(\mathrm{cm})$ & 155 & $18.50-36.00$ & $24.65 \pm 2.49$ & 6.245 \\
\hline Chest width $(\mathrm{cm})$ & 155 & $10.50-19.00$ & $15.53 \pm 1.62$ & 2.650 \\
\hline $\begin{array}{l}\text { Chest circumference } \\
(\mathrm{cm})\end{array}$ & 155 & $51.00-76.00$ & $63.34 \pm 5.06$ & 25.605 \\
\hline $\begin{array}{l}\text { Pastern circumference } \\
(\mathrm{cm})\end{array}$ & 155 & $6.00-11.50$ & $9.50 \pm .81$ & .667 \\
\hline Pelvis length $(\mathrm{cm})$ & 155 & $11.00-18.00$ & $15.58 \pm 1.41$ & 2.005 \\
\hline Rump width $(\mathrm{cm})$ & 155 & $4.00-10.00$ & $7.16 \pm 1.14$ & 1.306 \\
\hline Head length $(\mathrm{cm})$ & 151 & $19.00-26.00$ & $22.84 \pm 1.17$ & 1.381 \\
\hline Head width $(\mathrm{cm})$ & 151 & $9.00-14.00$ & $11.53 \pm 1.08$ & 1.174 \\
\hline Muzzle width (cm) & 151 & $4.00-8.00$ & $6.18 \pm 1.18$ & 1.396 \\
\hline Muzzle lenght (cm) & 151 & $5.00-9.50$ & $7.59 \pm 1.07$ & 1.151 \\
\hline Ear lenght $(\mathrm{cm})$ & 136 & $9.00-15.00$ & $11.69 \pm .90$ & .812 \\
\hline Hair lenght $(\mathrm{cm})$ & 89 & $.50-5.00$ & $2.84 \pm .83$ & .697 \\
\hline Valid N (listwise) & 87 & & & \\
\hline
\end{tabular}

If only the mean values of withers height and body length are observed for the total observed sample of Tazi, it can be seen that, generally, Tazi has a body whose length 
is almost equal to the height of the withers. The format index is 99.92 .

Table II. Descriptive statistic for morphometric parameters separately in males Tazi and females Tazi.

\begin{tabular}{|c|c|c|c|c|}
\hline & Sex & $\mathbf{N}$ & $\begin{array}{l}\text { Mean } \pm \text { Stand- } \\
\text { ard deviation }\end{array}$ & $\begin{array}{l}\text { Standard } \\
\text { error mean }\end{array}$ \\
\hline \multirow[t]{2}{*}{ Withers height } & Male & 88 & $62.02 \pm 2.88$ & 0.30761 \\
\hline & Female & 67 & $58.38 \pm 2.80$ & 0.34326 \\
\hline \multirow[t]{2}{*}{ Height of the back } & Male & 86 & $59.74 \pm 3.25$ & 0.35135 \\
\hline & Female & 67 & $56.66 \pm 3.20$ & 0.39191 \\
\hline \multirow[t]{2}{*}{ Height at rump } & Male & 86 & $61.75 \pm 3.27$ & 0.35348 \\
\hline & Female & 67 & $58.70 \pm 2.73$ & 0.33409 \\
\hline \multirow{2}{*}{$\begin{array}{l}\text { Height of the tail } \\
\text { root }\end{array}$} & Male & 85 & $56.90 \pm 3.31$ & 0.35948 \\
\hline & Female & 67 & $54.47 \pm 2.83$ & 0.34692 \\
\hline \multirow[t]{2}{*}{ Height of the hock } & Male & 88 & $16.19 \pm 1.382$ & 0.14734 \\
\hline & Female & 67 & $15.58 \pm 1.22$ & 0.15023 \\
\hline \multirow[t]{2}{*}{ Elbow height } & Male & 88 & $32.99 \pm 3.79$ & 0.40435 \\
\hline & Female & 67 & $31.88 \pm 1.77$ & 0.21657 \\
\hline \multirow[t]{2}{*}{ Body length } & Male & 88 & $61.73 \pm 3.18$ & 0.33922 \\
\hline & Female & 67 & $58.64 \pm 3.42$ & 0.41888 \\
\hline \multirow[t]{2}{*}{ Chest depth } & Male & 88 & $24.95 \pm 2.11$ & 0.22550 \\
\hline & Female & 67 & $24.26 \pm 2.89$ & 0.35401 \\
\hline \multirow[t]{2}{*}{ Chest width } & Male & 88 & $15.77 \pm 1.67$ & 0.17905 \\
\hline & Female & 67 & $15.22 \pm 1.51$ & 0.18488 \\
\hline \multirow[t]{2}{*}{ Chest circumference } & Male & 88 & $64.96 \pm 5.15$ & 0.54988 \\
\hline & Female & 67 & $61.22 \pm 4.07$ & 0.49777 \\
\hline \multirow{2}{*}{$\begin{array}{l}\text { Pastern circumfer- } \\
\text { ence }\end{array}$} & Male & 88 & $9.71 \pm .79$ & 0.08504 \\
\hline & Female & 67 & $9.24 \pm .77$ & 0.09414 \\
\hline \multirow[t]{2}{*}{ Pelvis length } & Male & 88 & $15.96 \pm 1.31$ & 0.14016 \\
\hline & Female & 67 & $15.07 \pm 1.39$ & 0.17022 \\
\hline \multirow[t]{2}{*}{ Rump width } & Male & 88 & $7.28 \pm 1.00$ & 0.10684 \\
\hline & Female & 67 & $7.00 \pm 1.29$ & 0.15825 \\
\hline \multirow[t]{2}{*}{ Head length } & Male & 84 & $23.27 \pm 1.06$ & 0.11655 \\
\hline & Female & 67 & $22.29 \pm 1.08$ & 0.13198 \\
\hline \multirow[t]{2}{*}{ Head width } & Male & 84 & $11.84 \pm 1.04$ & 0.11424 \\
\hline & Female & 67 & $11.14 \pm 1.00$ & 0.12310 \\
\hline \multirow[t]{2}{*}{ Muzzle width } & Male & 84 & $6.98 \pm 5.52$ & 0.60242 \\
\hline & Female & 67 & $5.94 \pm 1.24$ & 0.15267 \\
\hline \multirow[t]{2}{*}{ Muzzle lenght } & Male & 84 & $7.78 \pm 1.00$ & 0.10953 \\
\hline & Female & 67 & $7.35 \pm 1.11$ & 0.13618 \\
\hline \multirow[t]{2}{*}{ Ear lenght } & Male & 75 & $12.00 \pm .92$ & 0.10633 \\
\hline & Female & 61 & $11.31 \pm .71$ & 0.09206 \\
\hline \multirow[t]{2}{*}{ Hair lenght } & Male & 60 & $2.83 \pm .81$ & 0.10474 \\
\hline & Female & 29 & $2.86 \pm .89$ & 0.16627 \\
\hline
\end{tabular}

When looking at the frame index separately for each gender, it can be observed that males have an average format index of 99.5. On the other hand, females on average have a body that is square, that is, the length of the body is approximately equal to the height of the withers. The frame index in females is 100.44.

During the analysis of the measured parameters, the frame index for each individual dog was also calculated. The minimum value of frame index established in the observed population sample was under 89, and the maximum frame index established was over 115 (Table III). The highest percentage of individuals in the observed sample $(41.3 \%)$ has a frame index greater than 100 , while the smallest percentage $(18.1 \%)$ of the individuals in the observed sample has a frame index equal to 100 . Other individuals in the observed population (40.6\%) have frame index minor than 100 . These results indicate that there are three groups within dog of Tazi breed, from the aspect of frame index. For further analysis, they were divided into tree subpopulations. The first group consisted of individuals whose height of the withers was less than the length of the body (frame index was greater than 100) and this group was called the "rectangular frame dogs". The second group consisted of individuals whose height at the withers was equal to the length of the body (frame index was equal to 100). This group was called the "square frame dogs". The third group consisted of individuals whose body length was inferior to the height at the withers (frame index was less than 100). This group was called the "inverted rectangular frame dogs".

Table III. Body frame index.

\begin{tabular}{llll}
\hline & N & Min-Max & Mean \pm SD \\
\hline Body frame index & 155 & $88.89-115.38$ & $100.004 \pm 4.65$ \\
Valid N (listwise) & 155 & & \\
\hline
\end{tabular}

An analysis of variance (ANOVA) was conducted to determine if there were differences in the mean values of the measured parameters between these three groups revealed within the observed population. The "homogeneity of variance test" examined the equality of variance in each of the three groups. The homogeneity of variance was determined at the $\mathrm{HR}, \mathrm{HTR}, \mathrm{HH}, \mathrm{EH}, \mathrm{CD}$, CC, RW, HL, HW, ML, EL and HL ( $P>0.05$, Table IV). Other parameters were $P<0.05$ and Welch and BrownForsythe test was used.

The results of the ANOVA show that among the mentioned groups there is a significant statistical difference in the mean values of the parameters of the HR F $(2,150)$ $=8.067, P=0.000 ;$ HTR F $(2,149)=4.269, P=0.016$ and 
EH F $(2,152)=3.416, P=0.035($ Table V).

Table IV. Equality of variance in each of the three groups.

\begin{tabular}{lllll}
\hline & Levene statistic & df1 & df2 & Sig. \\
\hline Withers height & 3.70 & 2 & 152 & 0.027 \\
Height of the back & 4.02 & 2 & 150 & 0.020 \\
Height at rump & 2.54 & 2 & 150 & 0.082 \\
Height of the tail root & 0.53 & 2 & 149 & 0.590 \\
Height of the hock & 0.27 & 2 & 152 & 0.766 \\
Elbow height & 1.26 & 2 & 152 & 0.286 \\
Body length & 4.95 & 2 & 152 & 0.008 \\
Chest depth & 0.27 & 2 & 152 & 0.760 \\
Chest width & 6.06 & 2 & 152 & 0.003 \\
Chest circumference & 1.33 & 2 & 152 & 0.268 \\
Pastern circumference & 0.53 & 2 & 152 & 0.590 \\
Pelvis length & 8.57 & 2 & 152 & 0.000 \\
Rump width & 2.19 & 2 & 152 & 0.115 \\
Head length & 0.62 & 2 & 148 & 0.537 \\
Head width & 0.69 & 2 & 148 & 0.545 \\
Muzzle width & 4.44 & 2 & 148 & 0.013 \\
Muzzle lenght & 1.28 & 2 & 148 & 0.280 \\
Ear lenght & 0.48 & 2 & 133 & 0.621 \\
Hair lenght (HL) & 1.59 & 2 & 86 & 0.208 \\
\hline Sig, signifac; & & & &
\end{tabular}

Sig, significance; df, degrees of freedom.

Table V. Analysis of variance - ANOVA.

\begin{tabular}{lllllll}
\hline & & $\begin{array}{l}\text { Sum of } \\
\text { squares }\end{array}$ & df & $\begin{array}{l}\text { Mean } \\
\text { square }\end{array}$ & F & Sig. \\
\hline $\begin{array}{l}\text { Heights } \\
\text { at the }\end{array}$ & Between groups & 170.45 & 2 & 85.23 & 8.07 & 0.000 \\
rump & Within groups & 1584.77 & 150 & 10.57 & & \\
& Total & 1755.23 & 152 & & & \\
$\begin{array}{l}\text { Height } \\
\text { of the }\end{array}$ & Between groups & 90.83 & 2 & 45.42 & 4.27 & 0.016 \\
tail root & Within groups & 1585.19 & 149 & 10.64 & & \\
\multicolumn{1}{l}{$\begin{array}{l}\text { Elbow } \\
\text { height }\end{array}$} & Between groups & 64.77 & 2 & 32.38 & 3.42 & 0.035 \\
& Within groups & 1440.94 & 152 & 9.48 & & \\
& Total & 1505.71 & 154 & & & \\
\hline
\end{tabular}

Df, degrees of freedom; F-value, variation between sample means variation within the samples; Sig, significance.

The Welch and Brown-Forsythe test indicate that there is a statistically significant difference between the three groups of dogs in the parameters of withers height, height of the back, body length (Table VI).

Table VI. Analysis of variance, the Welch and Brown-Forsythe test.

\begin{tabular}{llllll}
\hline & & Statistic $^{\mathbf{1}}$ & df1 & df2 & Sig. \\
\hline Withers & Welch & 7.51 & 2 & 89.97 & 0.001 \\
height & Brown-Forsythe & 8.66 & 2 & 146.07 & 0.000 \\
Height of & Welch & 5.35 & 2 & 90.19 & 0.006 \\
the back & Brown-Forsythe & 6.89 & 2 & 148.57 & 0.001 \\
Body & Welch & 12.95 & 2 & 89.50 & 0.000 \\
length & Brown-Forsythe & 16.20 & 2 & 142.64 & 0.000 \\
\hline
\end{tabular}

a, asymptotically $\mathrm{f}$ distributed; Sig, significance; $\mathrm{df}$, degrees of freedom.

Thus, for these parameters there are statistically significant differences between these groups. At least one of the group means is significantly different from the others (or at least two of the group means are significantly different from each other). Subsequent comparisons using the Tukey HSD test and the Games-Howell test also show the exact differences between the groups, that is, how the groups differ statistically at the $P$ level is less than 0.05 . The "inverted rectangular frame dogs" were statistically significantly different in mean withers height values $(\mathrm{M}=$ $61.67, \mathrm{~S}=3.234)$ than "square frame dogs" $(M=60.00$, $\mathrm{SD}=2.56213)$ and "rectangular frame dogs" $(\mathrm{M}=59.40$, $\mathrm{SD}=3.52532$ ), while there is no difference in withers height between square and rectangular dogs. The "inverted rectangular frame dogs" differed significantly in $\mathrm{HB}(\mathrm{M}=$ $59.4921, \mathrm{SD}=3.68026)$ with "rectangular frame dogs" $(\mathrm{M}=57.3417, \mathrm{SD}=3.64121)$. The "inverted rectangular frame dogs" were significantly different in mean values of $\mathrm{HR}(\mathrm{M}=61.6746, \mathrm{SD}=3.24803)$ than "square frame dogs" $(\mathrm{M}=59.7167, \mathrm{SD}=2.65123)$ and "rectangular frame dogs" $(M=59.4500, S D=3.50991)$, while there is no difference in HR between square and rectangular frame dogs. The "inverted rectangular frame dogs" statistically significantly differed in HTR $(\mathrm{M}=56.7079, \mathrm{SD}=3.30148)$ with "rectangular frame dogs" $(\mathrm{M}=54.9915, \mathrm{SD}=$ 3.35088). They also statistically significantly differed in EH $(M=33.0952, \mathrm{SD}=2.25198)$ with "rectangular frame dogs" $(\mathrm{M}=31.7083, \mathrm{SD}=4.19068)$. "Rectangular frame dogs" were statistically significantly different in mean $\mathrm{BL}(\mathrm{M}=62.1500, \mathrm{SD}=3.87441)$ from "square frame dogs" $(\mathrm{M}=60.0625, \mathrm{SD}=2.58641)$ and "inverted rectangular frame dogs" $(\mathrm{M}=58.9048, \mathrm{SD}=3.11197)$, however, there is no statistically significant difference in body length between square and "inverted rectangular frame dogs". 


\section{DISCUSSION AND CONCLUSION}

Previous research on this sighthound breed has shown only average values of individual morphological parameters and differences in them depending on gender, age or place of origin. However, the premise of this research was that there are several different varieties of Tazi, depending on the proportions of the body. This research has found that, generally, dogs of this breed are of square body, but there are varieties with other body frames. Within the observed population, which is, generally, square body frame, there are varieties with extremely shorter and extremely longer bodies relative to the height of the withers. This is very important, because when formulating an official breed standard, all possible variations of the frame index must be taken into account.

The results obtained in this study show that the mean height of the withers is $60.45 \mathrm{~cm}$ which is smaller than those obtained in previous studies (Yılmaz and Ertuğrul, 2011; Yilmaz et al., 2012), although the maximum height that approximated to the one mentioned was established by Tepeli (2003). The mean value of body length was 60.40 which is similar to the results of previous studies. Chest depth has been shown to be slightly larger than in previous studies (Yilmaz et al., 2012), but on the other hand, chest width and head length are slightly smaller. The values of the height of the withers, the height of the back, the height at the rump, the height of the tail root in males were higher compared to the same parameters in females. These indicate that sex dimorphism has been developed. The Tazi males have slightly smaller length compared to the withers height. On the other side, Tazi females are proportionally longer in body. Although the absolute mean values of body length in females are smaller than in males, the proportions of females' bodies indicate that females are slightly longer in body than males. This is expected, given the reproductive function that females have.

Measurement results of 19 morphometric parameters showed that there are statistically significant differences between three sub-populations of Tazi, one with a frame index greater than 100, the other with a frame index less than 100 and a third with a frame index equal to 100 . "Inverted rectangular frame dogs" are generally taller than others, with higher back, higher rumps and body lengths shorter then withers height. Their tail is a bit more set than in other dogs. Such results are significant for setting the official race standard in which the proportions of the body characteristic of this race should be emphasized.

Statement of conflict of interest

The authors have declared no conflict of interest.

\section{REFERENCES}

Celik, S. and Yilmaz, O., 2018. Prediction of body weight of Turkish tazi dogs using data mining techniques: Classification and regression tree (CART) and multivariate adaptive regression splines (MARS). Pakistan J. Zool., 50: 575-583. https://doi. org/10.17582/journal.pjz/2018.50.2.575.583

FCI breeds nomenclature, 2020. Fédération Cynologique Internationale Website. Available at: http://www. fci.be/en/nomenclature/10-Sighthounds.html

Matejević, M., 2017. Kinološki aspekti lovnog turizma u Srbiji (Cynology aspects of hunting tourism in Serbia). Department of geography, tourism and hotel management, Faculty of Science, pp. 191.

Taubert, H., Agena, D. and Simianer, H., 2007. Genetic analysis of racing performance in Irish greyhounds. J. Anim. Breed Genet., 124:117-123. https://doi. org/10.1111/j.1439-0388.2007.00643.x

Tepeli, C., 2003. Some morphological characteristics in Turkish Tazi (Turkish hunting dog). pp. 124. II.

Urošević, M. and Drobnjak, D., 2019. Metodologija morfometrije pasa (Dog morphometry methodology). Kinološka akademija, Beograd.

Urošević, M., 2006. Srpski i slični goniči (Serbian and similar hounds). Kinološki savez Srbije i Crne Gore, Ljubostinja, Trstenik

Yilmaz, O., 2018. Hunting dog breeds of Turkey. Int. J. Livest. Res., 8: 1-5. https://doi.org/10.5455/ ijlr.20170923124626

Yilmaz, O., Coskun, F. and Ertugrul, M., 2012. Live weight and some morphological characteristics of Turkish Tazi (Sighthound) raised in Province of Konya in Turkey. J. Livest. Sci., 3: 98-103. https:// doi.org/10.5455/ijlr.20130109095630

Yilmaz, O. and Ertugrul, M., 2012. Live weight and some morphological characteristics of Turkish Tazi (Sighthound) raised in Province of Sanliurfa in Turkey. J. Vet. $A d v$., 2: 500-506.

Y1lmaz, O. and Ertuğrul, M., 2011. Some morphological characteristics of Turkish Tazi (Sight Hound). $J$. Anim. Pl. Sci., 21: 794-799.

Y1lmaz, O., 2008. Turkish Kangal (Karabash) shepherd dog. Impress Printing, Ankara, pp. 24. 